\title{
INTANGIBLE ASSETS AS FINANCIAL PERFORMANCE DRIVERS OF IT INDUSTRY: EVIDENCE FROM AN EMERGING MARKET
}

\author{
Milenko Radonićn ${ }^{1}$ Miloš Milosavljević², Snežana Knežević ${ }^{3}$
}

\footnotetext{
1 University of Belgrade, Faculty of Organizational Sciences, Department of Management, Serbia, ORCID: 0000-0003-2140-7494, radonic.milenko@gmail.com;

2 University of Belgrade, Faculty of Organizational Sciences, Department of Financial Management, Serbia, ORCID: 0000-0002-4965-4676,milosavljevic.milos@fon.bg.ac.rs;

3 University of Belgrade, Faculty of Organizational Sciences, Department of Financial Management, Serbia, ORCID: 0000-0001-9833-7274, snezana.knezevic@fon.bg.ac.rs.
}

\begin{abstract}
In the past few decades, IC has been viewed as a crucial factor for improved financial performance of IT companies. Globally, the IT industry has shown positive trendlines and the tremendous importance of intangible resources as part of intellectual capital. Intellectual capital per se may not be a novel topic in the IT industry. Nonetheless, this paper focuses on determining which type of intellectual capital is paramount for financial success, which has remained an open puzzle. The aim of this paper is to analyse the human, relational, structural and innovation capital of IT companies and to measure their impact on financial performance. Moreover, the authors have analysed the impact of the intellectual capital elements on several key performance indicators as the most frequently used in these kinds of studies. In order to address this aim, the study collected primary data from 101 respondents - business owners, managers and experts from a rapidly growing IT ecosystem in South-East Europe. Most research has focused on developed countries for addressing similar topics. Therefore, the authors call out for additional research of this topic in other emerging and developing environments. The findings of this study indicate a positive effect of intellectual capital on business performance. This study raises awareness among business experts in the field of intellectual capital, and supports decision-making through the concept of identifying, managing and analysing intellectual capital and its effect on overall business results. Even though the IT industry has become global, this study draws exceptional attention to the interplay between IC and financial performance in a developing IT ecosystem setting.
\end{abstract}

Keywords: Intellectual capital, IT industry, emerging markets, financial performance, intangible assets.

JEL Classification: E22, G32, O34, L25, J24.

APA Style Citation: Radonić, M., Milosavljević, M., \& Knežević, S. (2021). Intangible Assets as Financial Performance Drivers of IT Industry: Evidence from an Emerging Market. E\&M Economics and Management, 24(2), 119-135. https://doi.org/10.15240/tul/001/2021-2-008

\section{Introduction}

Intellectual capital has been a widely discussed topic in the last few decades (Palaščáková et al., 2019). The early research was solely focused on human capital as a strategic resource of a company (Hermanson, 1964). Follow up studies included a myriad of different elements of intellectual capital, i.e. structural and relational capital (Edvinsson,
1997; Pulić, 1998; Sveiby, 1997). Even though these authors have presented the structure of the intellectual capital, the consensus on the classification still has not been clearly set. Some authors propose separating innovation capital from structural capital in the IT industries (Wang \& Chang, 2005). Therefore, this study has followed the overview and classification of intellectual capital into four categories: human 
capital, relational capital, structural capital and innovation capital. With the development of the IT industry, innovation capital gained a significant role through its standard elements such as software, application patents and other parts of intellectual property. Even though there is a transition from manufacturing to service industries, service companies do not show a sufficient interest in intellectual property rights as manufacturing companies (Tsakalerou, 2018).

As intangible resources count for over $75 \%$ of the total assets in value (Kaplan \& Norton, 2004), it is of great importance to find the best way to identify and manage intellectual capital in order to boost the financial performance of a company. Current literature indicates the positive impact of intellectual capital on business performance (Andreeva \& Garanina, 2017; Bontis \& Fitz-enz, 2002; Chen et al., 2004; Ferraro \& Veltri, 2011; Gallego \& Rodríguez, 2005; Hussinki et al., 2014; Mondal \& Ghosh, 2012; Sardo \& Serrasqueiro, 2017; Steenkamp \& Kashyap, 2010). Therefore, this research field shows the relevance of this topic on emerging markets.

By measuring and structuring the importance of each element of intellectual capital, authors have given a guideline about the main foci for IT companies. Some older research has measured the importance of intellectual capital by top management in different industries. It was shown that company reputation, product reputation, and employee know-how are the most valuable and most important parts of intellectual capital (Hall, 1992). By focusing more on the IT industry, Wang and Chang (2005) have shown the other perspective of importance, focusing on the relationship among intellectual capital segments.

The objective of this paper is to examine the relationship between each segment of the intellectual capital structure and the following financial performance indicators: net profit, added value (net profit/FTE), sales, productivity (sales/FTE), return on equity (ROE) and return on assets (ROA).

Whereas global accounting institutions and standards (IFRS and GAAP) still do not have a clear vision on valuing the intellectual capital and showing it in the official financial statements, some authors have proposed models for reporting intangible resources. Some well-known models are the Balanced
Scorecard by Kaplan and Norton (1992), Skandia IC Report method by Edvinsson and Malone (1997), Sveiby's Intangible Asset Monitor (1997), Pulic's VAIC Model (1997). Ordóñez de Pablos (2003) showed the use of another holistic model for intellectual capital reporting in Spanish companies in her paper. Even though the vast majority of these models are tested in developed countries, there is research which points out the use of these models in an emerging market as well.

The remainder of this paper is organised as follows. Section 1 provides a literature review, by identifying a resource-based view on intellectual capital as a driving force of financial performance. Afterwards, this section develops hypotheses and depicts the business case for a geographical context of this study. Section 2 delineates the research methodology used for the study, putting particular emphasis on the development of measurements and variables and the sampling procedure. Section 3 elaborates on the results of the study. Section 4 contextualises the study results by providing an explanation of key findings, contributions, implications, limitations and further recommendations. The final part of this section is reserved for concluding remarks.

\section{Literature Review}

Throughout the paper, there will be several topics discussed as part of the existing studies, including the overview of intellectual capital, segmentation of intellectual capital and the business case for Serbia.

\subsection{Resource-based View on Intellectual Capital}

Gaining advantage in a highly competitive environment requires the deployment of various physical, human and organisational resources and competences. A resource-based view posits that if these resources and capabilities are valuable, rare, and hard to imitate, they have the potential to unlock strategic advantage on the marketplace (Kozlenkova et al., 2014). In the IT industry, technology is certainly an important resource (Chorev \& Anderson, 2006). However, in the long run, technology can be easily replicated. Intellectual capital is, on the other hand, hardly mimicable and can play a pivotal role in improving business and financial performances (Kianto et al., 2017). 
In concert with the resource-based view line of reasoning, intellectual capital has been viewed as a critical success factor in all service industries.

Awareness of intellectual capital has been tested in several studies. Hall (1992) has provided empirical evidence of IC awareness among 95 UK CEOs, by determining the importance of intangible resources. The most important factors were a company's reputation (brand), product reputation, company culture and know-how. Later on, intangible resources switched the importance to human capital as the key factor which generates the other parts of intellectual capital (Bontis et al., 1999). Human capital was the first aspect of intangible assets that became interesting for the academic community. Hermanson (1964) first mentioned human capital from an accounting perspective, by measuring its efficiency. Steenkamp and Kashyap (2010) measured the perception level by SME managers of intellectual capital. According to their research, customer satisfaction and loyalty are the key success factor (relational capital), followed by the company and product reputation, as well as employee knowhow. In their recent study, Wahyuningtyas et al. (2018) also showed the relevance of relational, human, and structural capital, retrospectively in the Tofu industry in Malaysia. In a panel study with 30 experts, Malhotra and Mehrotra (2019) presented a level of disclosure of intellectual capital in larger Indian companies. The highest levels of disclosure were in the relational capital. With the rise of the "customer-centric" concept which is commonly used by IT companies, these results are completely aligned with the trend of the modern organisation. The fact that almost every list of global "top customer-centric" companies has an IT company on it, shows the global impact of relational capital and positions its elements as highly important for business performance.

Researches has frequently presented a positive correlation between intellectual capital or some of its elements and financial performance in different industries. By analysing 75 publicly traded companies from South Africa, Firer and Williams (2003) have adopted the Pulic's VAIC method to check the relationship between profitability (ROA), productivity (turnover of company assets), market value of the company ( $\mathrm{P} / \mathrm{B}$ ratio) and intellectual capital. However, the empirical results did not show a significant effect of intellectual capital (measured by VAIC), profitability, and productivity. On the other hand, there was a positive correlation between intellectual capital and the market value of the companies. Additional studies have presented different results in further research. Basuki and Sianipar (2012) have shown a positive correlation between Pulic's Value Added Coefficient for measuring the intellectual capital and ROE in the banking and insurance industries. Andreeva and Garanina (2017) have analysed the effect of intangible assets on the financial performance of Russian manufacturing companies. The effect of human and structural capital is positive, while the effect of relational capital is not significant, due to the nature of the manufacturing industry. In the 2004 survey by Chen et al. which was conducted by 31 hightech companies in China (out of 60 companies), most entrepreneurs or senior managers pointed out a positive correlation between each segment of intellectual capital and financial performance. Using data from two industries in Malaysia, Bontis et al. (2000) showed the importance of developing structural capital and its positive impact on the financial performance of companies, no matter the industry. In another piece of research, Chen et al. (2004) observed the positive relationship between company value, profitability and its intellectual capital through the analysis of all firms listed on the Taiwan Stock Exchange during 1992-2002 (4.254 company years in total). According to Hollis (2004) and the results from a global survey, $94 \%$ of managers stated that intellectual capital is an important management issue and almost half of them reported that intellectual capital is crucial for generating long-term shareholder wealth. In [the Republic of] Serbia, there are several studies that show the positive impact of intellectual capital on financial performance in multinational companies (Komnenic \& Pokrajčić, 2012) and in the ICT industry (Dženopoljac et al., 2016). Pulic (1998) shows the significance of the VAIC method for traditional industries, by using the capital employed efficiency, efficiency of using human and structural capital. Since the establishment of the VAIC method, it remained one of the most popular methods for IC valuation.

In essence, a myriad of studies recognises a positive relationship between intellectual capital and financial performance. Most of them were performed in developed markets (Bontis, 1998; 
Bontis et al., 2000; Bontis \& Fitz-enz, 2002; Chen et al., 2004; Gallego \& Rodríguez, 2005; Lantz \& Sahut, 2005; Mondal \& Ghosh, 2012; Riahi-Belkaoui, 2003; Sardo \& Serrasqueiro, 2017; Zhang, 2017). However, there are some which were done on emerging and developing (EDE) markets (Bontis et al., 2000; Andonova \& Ruíz-Pava, 2016; Andreeva \& Garanina, 2017; Dženopoljac et al., 2016; Komnenic \& Pokrajčić, 2012). Most of the studies rely on Pulic's Value Added Coefficient (VAIC) method for valuing intellectual capital and checking the correlation with financial performance indicators. Due to the increased importance of customer satisfaction, loyalty and relational capital in general (Steenkamp \& Kashyap, 2010), the use of the VAIC method for measuring intellectual capital is not fully applicable to the IT industry, considering the fact that a specific measure for relational capital is yet to be established. On the other hand, Chen et al. (2005) discuss that the VAIC method may be incomplete due to R\&D and advertisement which are excluded from the calculation of value added even though they have a significant role in modern businesses. Several studies have shown that an increase in R\&D expenditure positively affects earnings and a company's market value (Hall, 1993). Sougiannis (1994) has presented in his research that each dollar invested into R\&D generates $\$ 2$ in increased earnings and $\$ 5$ in increased market value. On the other hand, Deeds (2001) focused more on the tech industry, primarily startups. Based on this research, investment in R\&D not only affects the current business results, but also future performance.

Considering all the facts, this study examines the empirical evidence based on the perception of business owners, investors and managers, in order to measure the importance of intellectual capital and its influence on financial performance. The authors have shown a special interest in one of the fastest growing industries in Serbia by focusing on its IT industry.

\subsection{Human Capital and Financial Performance}

Although the existing research has proven that intellectual capital has a positive impact on the financial performance of a company, the intensity of the relationship between them depends on the type of industry and type of organisation. Some earlier research has shown that company brand and its reputation have the highest influence (Hall, 1992), while some recent research has proven that the customer relationship has a big influence on the business results of the company (Steenkamp \& Kashyap, 2010; Vlastelica et al., 2018). On the other hand, Wang and Chang (2005) have shown that each part of intellectual capital has a positive impact on financial performance. However, it was shown that human capital has an indirect influence on a company's performance through the other segments of intellectual capital. Knowhow is one of the human capital elements that was the most important throughout business history. Considering the fact that human capital directly generates and affects other elements of intellectual capital, it could be said that it is the ultimate and most fundamental part of intellectual capital.

Following the aforementioned, this study hypothesises that:

H1: Human capital positively affects financial performance.

\subsection{Relational Capital and Financial Performance}

Relational capital has become one of the most important parts of intellectual capital, especially in the era of web businesses. As the first hypothesis is related to human capital, the second hypothesis tested the relation between relational capital and a company's financial performance indicator (elements like customer satisfaction, customer loyalty and other important parts of relational capital have been tested).

H2: Relational capital positively affects financial performance.

\subsection{Structural Capital and Financial Performance}

Some authors use the term structural capital as a combination of processes and innovation. However, in this paper structural capital will be focused only on processes, which include process automation, management methodology, databases, together with other elements as well (Milosavljevic et al., 2017). Structural capital is crucial for later stages of business development and is proven to have an impact on business performance. The authors of this paper will also test the participants' perception of the relationship between 
structural capital and the abovementioned financial performance indicators.

H3: Structural capital positively affects financial performance.

\subsection{Innovation Capital and Financial Performance}

In the web development and IT industries, innovation capital has gained another perspective. Innovation activities and innovation concepts have a huge impact on today's businesses (Peterková \& Zapletalová, 2018), that is why innovation capital should be treated and analysed as a separate segment of intellectual capital.

Evolving from the traditional model of enterprise to modern businesses, it is important to track innovation through business digitalisation (Radonić \& Knežević, 2018). Product reputation, beside patents and copyrights, is highly related to innovation capital. Therefore, testing the relationship between innovation capital and financial performance is necessary for IT companies.

H4: Innovation capital positively affects financial performance.

On the other hand, product development and product reputation are highly related to relational capital and customer satisfaction. The other parts of intellectual capital are also connected. Therefore, in order to reach the full business potential by proper management of intellectual capital, stakeholders should not neglect any part of it. This paper gives insight into the relevancy of some of the elements and tracks the relationship intensity between those elements and the financial performance indicators based on the participants' perception.

\subsection{Business Case for Serbia}

The IT industry in Serbia is one of the fastest growing industries, recording a constant growth year-over-year. It has reached first place as the biggest export potential for all products and services that Serbia offers. As a small country, through the IT industry, Serbia has a huge potential to make a global impact with its products, considering the fact that investment in ICT is $\$ 80$ per capita, compared to $\$ 800$ per capita in the EU (Milosavljevic et al., 2019). Speaking of the Serbian ICT market, according to the OECD it could be separated into two main categories: Telecommunication and IT industries. The main focus throughout this paper will be the IT industry.

By analysing the nature of the IT industry in general, intangible resources have a big role in transforming local companies into global ones. Intellectual capital is the key driver which could help the Serbian IT sector position itself among the leading global IT companies. Moreover, the existing literature and research explains the concept and structure of intellectual capital, without focusing on showing the relationship between intellectual capital and the financial performance of companies.

\section{Research Methodology}

The study was based on primary data collected by a questionnaire. The questionnaire was distributed to 625 practitioners. The participants' knowledge of the concept of intellectual capital was pre-tested to ensure that only key informants participate.

\subsection{Measures and Variables}

Measuring the value of intellectual capital is a difficult and a non-standardised task. Considering its influence on business performance and the fact that it is one of the most valuable strategic assets, it is crucial to know how to manage intellectual capital, especially in emerging and developing economies like Serbia.

Selected financial performance indicators presented in this paper were taken as the representative dependent variables. The first variable to be analysed was net profit as a difference between total sales and total cost (Rakočević et al., 2014). This indicator is a commonly used variable to measure the relationship between intellectual capital and financial performance. Wang and Chang (2005) propose to use the productivity and efficiency indicators to measure the relationship strength. Therefore, the next variable is added value, which is obtained by dividing net profit and the number of full-time employees. It shows how much added value is created by each employee, not counting the contractors or freelancers. Sales is the third variable which is used as an input to some of the other variables (as well as net profit). Productivity is also an extended indicator which includes sales divided by the number of full-time employees, presenting how much value is generated in average by each employee. The last two indicators - ROE and 
ROA - are used to measure the efficiency of using shareholders' equity and the assets of the company. By using the Pulic's VAIC method, Dženopoljac et al. (2016), have presented in their study a positive impact of intangible assets on profitability ratios, focusing on net profit, $\mathrm{ROA}$ and ROE as the financial performance variables. Similarly, Firer and Mitchell (2003) have used the VAIC method to analyse the effects of intangible assets on ROA, sales metrics and market share. By focusing on ROA and ROE, Mondal and Ghosh (2012) have analysed the effects of intangible assets on selected financial performance indicators in the Indian banking sector, while in another study by Zhang (2017), the significant and positive impact of intangible assets on ROA in China's telecommunication companies. Most of these studies have been focused on using the VAIC method to determine the effects of intangible assets, where there is a lack of empirical studies.

These variables have frequently been used in similar empirical studies which are related to measuring the relationship between the parts of intellectual capital and the financial performance indicators.

By analysing the relationship between intellectual capital and financial performance indicators, the authors first used the general term financial performance indicators in pre- analysis to measure the effect of each element of intellectual capital (22) on a company's overall business performance. In the main analysis, the authors have afterwards used the concrete indicators (dependent variables) as shown in Fig. 1 to test the effect of each segment of intellectual capital on financial performance. The target group and the methodology for collecting the inputs for this research are further explained.

\subsection{The Structure of the Participants and Their Companies}

Through the questionnaire, the authors have segmented the participants based on their seniority and position, as well as their role. Considering the position, the targeted participants were business owners/co-owners, top managers, consultants, other managerial levels (within sales, marketing, HR, product) and investors. On the other hand, their main roles vary from advisory positions to R\&D and human resources. Each of those positions is related to the management of intellectual capital.

Most of the answers came through direct channels (direct emails sent from the authors) - $77.2 \%$ (78 respondents). The remaining $22.8 \%$ of participants (23 respondents) were approached by using snowball sampling. Taking into account that some of the main target groups (especially business owners, investors

\section{Fig. 1: Relationship between the intellectual capital parts and the financial performance indicators}

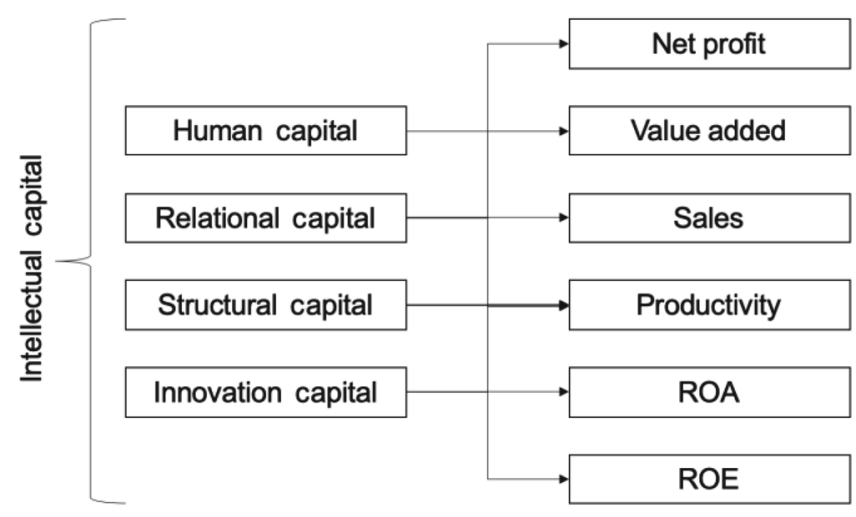


and senior managers) are difficult to reach, snowball sampling mostly applied to some of the professional organisations. Out of these 23 respondents, 10.9\% (11 respondents) came from the CFO Association of Serbia, 2.0\% (two respondents) from IT Associations, and 9.9\% (10 respondents) through recommendations from other respondents.

\subsection{Questionnaire Design}

The questionnaire was structured into four segments of questions with offered answers and text input answers. The first two parts of the survey were related to the participants' data (including their work experience and their expertise) as well as the company data. Based on those answers, the authors diversified the relevant from irrelevant data for analysis. In Section 3, participants' perception about the relation between different types of intellectual capital elements and the financial performance of an IT company were assessed (see Tab. A1 in Appendix). Every part of intellectual capital is broken into multiple key "intangible" indicators (22 indicators). The vast majority of elements (indicators) were observed in the study by Natasja et al. (2010). The number of full-time employees was used as an indicator in a study by Wang and Chang (2005), while the use of a product (software/hardware) without bugs or failures was analysed by Gallego and Rodriguez (2005). Company and product reputation as brand representatives were analysed in some earlier studies by Hall (1992).

Section 4 had more specified financial performance indicators. In this section, each part of intellectual capital (human capital, relational capital, structural and innovational capital) was put in correlation with the indicators mentioned in the introduction. Similar correlations have already been checked in other industries and markets by several authors (Andreeva \& Garanina, 2017; Mondal \& Ghosh, 2012; Wang, 2008; Wang \& Chang, 2005).

The whole questionnaire used a Likert scale of 1 to 5 in the questions where perception is measured (1 - I totally disagree; 2 - I disagree; 3 - I neither agree nor disagree; 4 - I agree; 5 - I totally agree). Considering that similar questionnaires already exist, the authors used a combination of several questionnaires from research on different markets and for different industries in order to test the hypothesis on the Serbian IT market. Both Serbian and English versions of the final version of the questionnaire is available upon request to the authors.

\subsection{Responses}

This study performed with a low response rate. Out of 625 reached potential participants, 107 finished the questionnaire and 101 were accepted. The answers from six respondents were rejected due to not being recognised as experts in the field of managing intangible assets or not being the target group. These respondents came through snowball sampling. Nonetheless, the target group consisted mainly of top managers, business owners, top and middle management and investors. Therefore, the results and response rate of $16.6 \%$ are not inconsistent with similar studies (Hall, 1992; Steenkamp \& Kashyap, 2010). Low response rate does not invalidate the perception of all participants. To that end, the empirical evidence of this population shows the importance of the collected answers. It is expected that the insights and findings from the participants' answers are relevant, especially for the IT industry in emerging economies, by focusing on Serbia. The results are discussed below.

\section{Results}

The results of this study were separated in three segments: demographics, pre-analysis and main analysis. The database composed by the authors is fully available upon request to the authors.

\subsection{Demographics}

Throughout the paper, the authors have focused on several key target groups: top/ senior management, middle management, lower management levels, consultants, business owners and investors. Out of 101 surveyed participants, 39\% represented top management, $26 \%$ middle management, $15 \%$ business owners and $21 \%$ lower management, consultants and investors.

Secondly, the type of organisation which the respondents come from has the highest allocation within corporations $(73 \%)$, startups $(14 \%)$, public companies $(3 \%)$ and other types $(5 \%)$. This data are aligned with the segmentation and the highest concentration of top/senior managers which represent corporations. Business owners mostly represent startup companies which have a similar percentage of answers (15\% of business owners represent $14 \%$ of startups). 
All of the respondents manage some part of intellectual capital, while $52 \%$ directly work in the IT industry. Having in mind that corporations in the IT industry specifically nowadays possess the most valuable intellectual capital worldwide, the response structure is in correlation with the expected target group.

\subsection{Pre-analysis}

There were a lot of attempts to make a general classification of intellectual capital with all of its constituents. Most of the previous studies and authors have used a framework which consists of three main parts - human, relational and structural capital (Bontis et al., 2000; Edvinsson \& Malone, 1997; Ordoñez de Pablos, 2005). However, in this study, the authors have used a modified segmentation of intellectual capital within IT companies, by dividing it into human, relational, structural and innovation capital. Nonetheless, all of these segments have a deeper degradation to multiple elements (see Tab. A1 in Appendix). The aim of this study was to show the relationship between each aspect of intellectual capital (including its elements) on the financial performance of a company. Therefore, the first part of this analysis was concerned with the overall business performance presented through descriptive statistics and correlation. Every surveyed expert expressed their opinion on the relationship between the intangible assets' elements and the financial performance of companies. Out of 101 surveyed experts, all of them stated that personal development and investment in employees has a strong impact on financial performance. Out of the top five highly rated elements, four are related to human capital. However, some human capital elements, such as the number of full-time employees, were rated poorly.

The authors have used the Cronbach's alpha test to check the reliability of the questionnaire for each segment of intellectual capital. By using Cronbach's alpha as the default method for measuring the internal consistency and reliability (Nunnally, 1978), the measured data have shown an acceptable value $(\alpha>0.7)$ for each intellectual capital segment.

For the purpose of this research, working experience and formal education level have been rejected from further analysis as part of the reliability check.

By reviewing intellectual capital segments as a whole, and analysing the data through

\section{Tab. 1: Cronbach's alpha - reliability test}

\begin{tabular}{l|c|c|c} 
& N of items & $\begin{array}{c}\text { Cronbach's } \\
\text { alpha }\end{array}$ & $\begin{array}{c}\text { Cronbach's alpha based } \\
\text { on standardised items }\end{array}$ \\
\hline Human capital & 6 & 0.724 & 0.704 \\
\hline Relational capital & 6 & 0.755 & 0.768 \\
\hline Structural capital & 5 & 0.729 & 0.731 \\
\hline Innovation capital & 3 & 0.740 & 0.758 \\
\hline
\end{tabular}

Source: own

\section{Tab. 2: The influence of intangible assets elements on the financial performance - Part 1}

\begin{tabular}{c|l|c|c|c|c|c|c|c}
$\#$ & \multicolumn{1}{|c|}{ Element of intellectual capital } & $\mathbf{1}$ & $\mathbf{2}$ & $\mathbf{3}$ & $\mathbf{4}$ & $\mathbf{5}$ & $\mathbf{M e a n}$ & $\begin{array}{c}\text { Type } \\
\text { of intellectual } \\
\text { capital }\end{array}$ \\
\hline 1 & Personal development and investment in employees & 0 & 0 & 0 & 29 & 72 & 4.71 & $\mathrm{HC}$ \\
\hline 2 & Customer satisfaction & 0 & 0 & 5 & 28 & 68 & 4.62 & $\mathrm{RC}$ \\
\hline 3 & Expertise of employees (knowledge and skills) & 0 & 0 & 5 & 31 & 65 & 4.59 & $\mathrm{HC}$ \\
\hline 4 & Employee's satisfaction & 0 & 2 & 6 & 29 & 64 & 4.53 & $\mathrm{HC}$ \\
\hline 5 & Employee's innovativeness & 0 & 2 & 10 & 27 & 62 & 4.48 & $\mathrm{HC}$ \\
\hline 6 & Loyalty and customer retention & 0 & 0 & 8 & 38 & 55 & 4.47 & $\mathrm{RC}$ \\
\hline
\end{tabular}




\section{Tab. 2: The influence of intangible assets elements on the financial performance - Part 2}

\begin{tabular}{r|l|r|r|r|r|r|r|c} 
\# & \multicolumn{1}{|c|}{ Element of intellectual capital } & $\mathbf{1}$ & $\mathbf{2}$ & $\mathbf{3}$ & $\mathbf{4}$ & $\mathbf{5}$ & $\mathbf{M e a n}$ & $\begin{array}{c}\text { Type } \\
\text { of intellectual } \\
\text { capital }\end{array}$ \\
\hline 7 & Product reputation & 0 & 0 & 9 & 42 & 50 & 4.41 & $\mathrm{IC}$ \\
\hline 8 & Employee's loyalty & 0 & 4 & 10 & 38 & 49 & 4.31 & $\mathrm{HC}$ \\
\hline 9 & Management and goal setting methodology & 1 & 1 & 9 & 45 & 45 & 4.31 & $\mathrm{SC}$ \\
\hline 10 & Company culture & 0 & 5 & 9 & 38 & 49 & 4.30 & $\mathrm{SC}$ \\
\hline 11 & Relations with investors & 0 & 1 & 19 & 52 & 29 & 4.08 & $\mathrm{RC}$ \\
\hline 12 & Processes (clear and transparent processes) & 0 & 2 & 18 & 52 & 29 & 4.07 & $\mathrm{SC}$ \\
\hline 13 & Relations with other stakeholders & 1 & 1 & 20 & 52 & 27 & 4.02 & $\mathrm{RC}$ \\
\hline 14 & Relations with suppliers & 1 & 7 & 13 & 55 & 25 & 3.95 & $\mathrm{RC}$ \\
\hline 15 & Bug free product & 0 & 7 & 19 & 48 & 27 & 3.94 & $\mathrm{IC}$ \\
\hline 16 & $\begin{array}{l}\text { Databases (structured and organised databases - } \\
\text { great back end) }\end{array}$ & 0 & 7 & 29 & 35 & 30 & 3.87 & $\mathrm{SC}$ \\
\hline 17 & $\begin{array}{l}\text { Working experience (number of years) - rejected from } \\
\text { analysis }\end{array}$ & 0 & 9 & 15 & 59 & 18 & 3.85 & $\mathrm{HC}$ \\
\hline 18 & Copyrights (on intellectual capital) & 2 & 7 & 24 & 40 & 28 & 3.84 & $\mathrm{IC}$ \\
\hline 19 & Number of customers (big customer database) & 1 & 12 & 18 & 43 & 27 & 3.82 & $\mathrm{RC}$ \\
\hline 20 & $\begin{array}{l}\text { Distribution agreements for products and services } \\
\text { (affiliates) }\end{array}$ & 0 & 3 & 37 & 41 & 20 & 3.77 & $\mathrm{SC}$ \\
\hline 21 & Formal education level - rejected from analysis & 4 & 21 & 17 & 47 & 12 & 3.42 & $\mathrm{HC}$ \\
\hline 22 & FTE (\# of full-time employees) & 6 & 43 & 34 & 16 & 2 & 2.65 & $\mathrm{HC}$ \\
\hline
\end{tabular}

\section{Tab. 3: Descriptive statistics}

\begin{tabular}{l|c|c|c} 
& Mean & Std. deviation & Variance \\
\hline Human capital & 4.2129 & 0.46255 & 0.214 \\
\hline Relational capital & 4.1601 & 0.51904 & 0.269 \\
\hline Structural capital & 4.0634 & 0.56280 & 0.317 \\
\hline Innovation capital & 4.0627 & 0.68103 & 0.464 \\
\hline Net profit & 4.0495 & 0.76650 & 0.588 \\
\hline Added value & 3.9307 & 0.82774 & 0.685 \\
\hline Sales & 4.0693 & 0.87473 & 0.765 \\
\hline Productivity & 4.0000 & 0.72111 & 0.520 \\
\hline Capital & 3.9010 & 0.74169 & 0.550 \\
\hline ROE & 4.0396 & 0.77357 & 0.598 \\
\hline ROA & 3.9208 & 0.78337 & 0.614 \\
\hline
\end{tabular}

Source: own

descriptive statistics, human capital has shown a significant influence on the financial performance indicators. The data shown in Tab. 3 also presents the key financial performance indicators which are being influenced the most by intellectual capital. The 
first indicator which is considered to be affected the most is sales, followed with net profit and ROA respectively. The remaining indicators are also affected by intellectual capital, by showing the mean value of more than 3 .

Even though this study tested the relationship between intellectual capital, its components and the financial performance of companies, there is a strong correlation between all segments of intellectual capital as presented in Tab. 4. This fact defines intellectual capital as a unique form of connected intangible resources through human, relational, structural and innovation capital. The intellectual capital segments could not create a significant impact on the overall business performance without their synergy. However, the strongest correlation was shown between relational and structural capital $(r=0.622 ; p<0.01)$. The relational and innovation capital have also shown a strong positive correlation $(r=0.589$; $p<0.01$ ), but structural and innovation capital as well $(r=0.586 ; p<0.01)$. In the study performed by Wang and Chang (2005) in the Taiwanese IT industry, similar results were presented. This was elaborated through the nature of the IT industry which could separate innovation capital as an individual intellectual capital segment.

\subsection{Main Analysis}

This section shows the empirical results related to the direct impact of the main intellectual capital parts on business performance (presented by several financial indicators). The relationship between them is analysed through the experts' opinions. The authors have transformed and analysed the data by using the SPSS and Microsoft Excel Statistics.

Considering the strong positive correlations between intellectual capital segments, but also

Tab. 4: Two-tailed correlation coefficient analysis between intellectual capital segments

\begin{tabular}{l|l|c|c|c|c}
\multicolumn{2}{|l|}{} & $\begin{array}{c}\text { Human } \\
\text { capital }\end{array}$ & $\begin{array}{c}\text { Relational } \\
\text { capital }\end{array}$ & $\begin{array}{c}\text { Structural } \\
\text { capital }\end{array}$ & $\begin{array}{c}\text { Innovation } \\
\text { capital }\end{array}$ \\
\hline \multirow{2}{*}{ Human capital } & Pearson correlation & & $0.501^{* *}$ & $0.476^{* *}$ & $0.414^{* *}$ \\
\cline { 2 - 5 } & Sig. (2-tailed) & & 0.000 & 0.000 & 0.000 \\
\hline \multirow{2}{*}{ Relational capital } & Pearson correlation & $0.501^{* *}$ & & $0.622^{* *}$ & $0.589^{* *}$ \\
\cline { 2 - 6 } & Sig. (2-tailed) & 0.000 & & 0.000 & 0.000 \\
\hline \multirow{2}{*}{ Structural capital } & Pearson correlation & $0.476^{* *}$ & $0.622^{* *}$ & & $0.586^{* *}$ \\
\cline { 2 - 6 } & Sig. (2-tailed) & 0.000 & 0.000 & & 0.000 \\
\hline \multirow{2}{*}{ Innovation capital } & Pearson correlation & $0.414^{* *}$ & $0.589^{* *}$ & $0.586^{* *}$ & \\
\cline { 2 - 6 } & Sig. (2-tailed) & 0.000 & 0.000 & 0.000 & \\
\hline
\end{tabular}

Note: ${ }^{* *}$ correlation is significant at the 0.01 level (2-tailed).

\section{Tab. 5: Correlation between intellectual capital segments and financial performance as a computed variable}

\begin{tabular}{l|c} 
& Fin. perf. \\
\hline Human capital & $0.403^{* *}$ \\
\hline Relations capital & $0.411^{* *}$ \\
\hline Structural capital & $0.456^{* *}$ \\
\hline Innovation capital & $0.538^{* *}$ \\
\hline
\end{tabular}


the strong correlation between the intellectual capital segments and the predefined financial performance indicators (as shown in Tab. 4), this study examined the effect of determinants (HC, RC, SC, IC) on financial performance indicators as a computed variable. One of the main characteristics of the intellectual capital is the collective effect of its segments on financial performance, focusing on the synergy among the intellectual capital segments (Haskel \& Westlake, 2018). Therefore, the isolated effects could be difficult to estimate. Similarly, the effects on one of the selected financial performance might affect the other ones. As a consequence, the authors have generated a single variable (Fin. perf.) as the mean between seven indicators. This approach for the condensation of measures into a variable was performed in the recent study on intellectual capital as well (see Radonic \& Milosavljevic, 2019).

As shown in Tab. 4, this study has identified a strong correlation between each intellectual capital segment and financial performance. Financial performance as a dependent variable was computed by using seven indicators to transform the mean (net profit, added value, sales, productivity, capital, ROA and ROE).

The study has identified a strong correlation between $\mathrm{HC}$ and financial performance $(r=0.403 ; p<0.01)$, but also between the other segments (RC, SC and IC) and financial performance, where IC has shown the strongest correlation in the IT industry with the financial performance indicators $(r=0.538$; $p<0.01)$. The data shown in Tab. 4 does not recognise $\mathrm{HC}$ as the intellectual capital segment with the smallest impact to the financial performance in comparison to the other segments. The study performed by Wang and Chang (2005) has shown that $\mathrm{HC}$ does not affect financial performance directly, but through the other segments - RC, SC and IC.

The authors have performed the multilinear regression model, using the intellectual capital segments as the independent variables and financial performance indicators as the dependent variables. The square of the correlation coefficient $\mathrm{R}^{2}$ (presented as the determination coefficient) shows that changes in the determinants ( $\mathrm{HC}, \mathrm{RC}, \mathrm{SC}$ and $\mathrm{IC})$ describe $16.2 \%, 16.9 \%, 20.1 \%$ and $28.9 \%$ of changes in the financial performance respectively. This data are dominantly oriented towards the IT industry, or some other industries and businesses related to IT industry environments.

Considering the strong relationship between the determinants and financial performance, this study has predetermined the influence of intellectual capital on financial performance. By analysing the results of the multiple regression, the data have shown that $34.3 \%$ of determinants predict the variance of the financial performance. On the other hand, the authors have used the Durbin-Watson test to check if there is a linear

\section{Fig. 2: Multilinear regression scheme}


autocorrelation. The results have indicated that the Durbin-Watson test lies between the critical values $d=2.167(1.5<d<2.5)$ and therefore shows no first order linear autocorrelation.

Each of the intellectual capital segments has also shown a significant correlation and influence on the financial performance indicators, confirming $\mathrm{H} 1, \mathrm{H} 2, \mathrm{H} 3$ and $\mathrm{H} 4$. Personal development and investment in employees is a key determinant, presenting human capital, followed by expertise. Loyalty and customer retention factor were shown as two of the key drivers for the financial performance of an IT company as part of relational capital. Management and goal setting methodology presented a key determinant of structural capital in the terms of affecting financial performance. On the other hand, the results of this study have shown that innovation capital has the strongest influence on the financial performance of an IT company, confirming $\mathrm{H} 4$. Product reputation is a key element which was even confirmed in older studies (Hall, 1992) as a key element of intangible resources. It is one of the main representatives of innovation capital. Copyrights and bug-free products came after product reputation.

\section{Discussion and Conclusions}

The intention of this paper is to show to what extent companies from emerging and developing countries perceive the potential of future value hidden in utilisation of intellectual capital. Furthermore, this question was explained through the four hypotheses: How can intellectual capital affect financial performance through its components (HC, SC, RC and IC). The study was performed in the Republic of Serbia as the EDE representative, with the main focus on the IT industry. By analysing each segment of intellectual capital and its influence on the business (financial) performance of companies, the authors gathered the data from an empirical research which was supported by the answers of 101 experts.

\section{Key Findings and Contributions}

This study raises awareness among the companies within the IT industry in understanding, identifying and managing intellectual capital, its segments and its elements. Through the gathered data, based on the perception of the experts, the authors have shown an overwhelmingly positive impact of intellectual capital on financial performance indicators.

Even though innovation capital has shown the strongest impact on financial performance, human capital is considered the most important segment by many studies (Bontis et al., 1999). Wang and Chang (2005) have observed in their study that human capital has an indirect impact on financial performance through the other segments. According to this study, human capital has the strongest impact on innovation capital. Furthermore, if companies want to improve innovation capital, they should improve human capital too. This study is aligned with the results presented by Wang and Chang.

By reviewing the descriptive statistics in the pre-analysis, it is obvious that human capital elements are considered to be the most important and the most influential parts of intellectual capital. Personal development and investment in employees are crucial, especially for economically developing countries. Employee satisfaction is highly connected to customer satisfaction, which was explained by Chi and Gursoy (2009). Therefore, the individual effect could hardly be assigned to the specific element of intellectual capital, considering the synergy between each intellectual capital segment. By analysing innovation capital, product and corporate reputation are rated as essential for the success of the SME (Steenkamp \& Kashyap, 2010). This study has also marked employee know-how, loyalty and satisfaction as HCs most valuable assets, which was confirmed in this paper as well.

One of the key problems concerning this topic is determining the structure of intellectual capital for the IT industry. The existing literature has supported this paper, by structuring intellectual capital into human, relational and structural capital (Edvinsson, 1997; Pulić, 1998; Sveiby, 1997). More specifically, the IT industry considered the fourth segment - innovation capital - as one of the most influential elements for this industry (Wang \& Chang, 2005).

The vast majority of studies dealt with the intangible resources and intellectual capital and their impact on financial performance within developed countries (Bontis, 1998; Bontis et al., 2000; Bontis \& Fitz-enz, 2002; Chen et al., 2004; Gallego \& Rodríguez, 2005; Lantz \& Sahut, 2005; Mondal \& Ghosh, 2012; Riahi-Belkaoui, 2003; Sardo \& Serrasqueiro, 2017; Zhang, 2017). Yet, only a few of them have focused on economically 
developing countries and the IT industry as a fast growing company (Dženopoljac et al., 2016; Wang \& Chang, 2005). Therefore, there is a lack of research on the topic for developing countries, considering that this topic differs in developed countries in comparison to the ones treated as developing economies.

This study has followed up the previous study by Wang and Chang (2005), where the relationships between intellectual capital segments have been determined. The authors of this paper have confirmed the strong correlation between each segment and shown a positive impact on the financial performance indicators, including net profit, added value, sales, productivity, capital, ROE and ROA.

This study is based on empirical research of the expert's perceptions and therefore supports the current research related to similar topics and expands the know-how.

\section{Implications}

This paper has both a social and theoretic contribution. It helps specify, understand and manage intellectual capital and its structure based on the intensity of affecting the financial performance of an organisation. Therefore, the organisations could make a better prioritisation and find the way to utilise intellectual capital better in order to maximise some business performance aspects.

The nature of intellectual capital is to provide the basis for future benefits and to be able to generate value (Dženopoljac et al., 2016). Due to the structure of intellectual capital which consists of intangible resources, without any physical embodiment, this paper has given the framework to recognise intangible resources and to structure them under the intellectual capital segments.

Additionally, by analysing the current literature, the authors have selected several metrics which represent financial performance and match them with intellectual capital in terms of their relationship. Furthermore, this paper helps to understand the intensity of the relationship and the nature of those relations.

\section{Limitation and Further Recommendations}

The authors call out for further research in other EDE countries, focusing on the IT industry, which could help understand the IT industry and intellectual capital within different economies. Due to globalisation of the business it is expected that the intellectual capital should have the similar impact in different economies (Azmi, 2011), especially focusing on the intellectual capital (Gubová \& Richnák, 2016). However, experts' perceptions could differ based on the country and industry. Therefore, it is of great importance to expand this research to other countries and industries. Even though the ICT industry is considered as a pioneer of globalization, this study is geographically constrained. As it conducted in Serbia, the generalizability of the findings to other regions is to some extant speculative and might lead to judicious judgments.

This study is fundamentally grounded, but not comprehensive. Even though there are tools and models for measuring intellectual capital, the authors of this paper have taken a holistic approach toward the research by surveying 101 experts. Considering the sample, the results could hardly be generalised. Nevertheless, by using this approach, the authors have avoided the weaknesses of other approaches. Also, the approach of measuring an expert's perception could vary with the type of organisation. By taking that into account, the authors have tested the reliability and internal consistency of the collected data.

Time delay of the intellectual capital effect is hardly recognisable. Therefore, the results may vary from the period where the data have been recorded. Despite this restriction, it should be clear that intellectual capital has a long-term influence on financial performance indicators. Thus, there is no instant effect on performance.

Additionally, the authors propose researching the effects and relationships between intellectual capital and financial performance, by using a case studies with specific organisations in the IT industry. By perceiving the business need of the industries, what might be most important about intellectual capital is how to find the best ways to utilise it (Bukh et al., 2001).

\section{Conclusions}

By taking into consideration the previous studies which have shown how intellectual capital affects the financial performance of companies in developed countries, this paper focuses on the IT industry as the key factor for boosting the GDP of those countries. In order to better understand intellectual capital, the authors have analysed various studies and models 
and proposed the framework for structuring the intellectual capital elements.

The first results indicated that personal development and investment in employees as the human capital representative is the most important factor which affects financial performance. The second most important element was customer satisfaction (as part of relational capital), followed by employees' expertise, employees' loyalty and employees' satisfaction. As presented in previous studies, human capital has the strongest influence on financial performance, but indirectly through the remaining segments. This study has shown that innovation capital with product reputation, copyrights and bug-free products, has the strongest influence. However, structural and relational capital have also shown a positive impact.

To summarise, all intellectual capital segments are aligned and act together, so it is not recommendable to isolate one specific segment. Many questions concerning the matter of intellectual capital stay unanswered. Therefore, this topic is still important to be further analysed. All in all, this study has shown the directions for managing intellectual capital to the key stakeholders within developing countries like Serbia, with a special accent on the IT industry. By showing the implications of intellectual capital effects, the authors of this paper have summarised the experts' insights on the importance of each segment and element.

Acknowledgement: This research was supported by the Serbian CFO Association, Startit IT Community, as well as Serbian Association of Managers. We would like to express our gratitude to all the experts who participated in this research. We would also like to thank the editors of the journal and two anonymous reviewers for their useful suggestions and highly beneficial comments.

\section{References}

Andonova, V., \& Ruíz-Pava, G. (2016). The role of industry factors and intangible assets in company performance in Colombia. Journal of Business Research, 69(10), 4377-4384. https://doi.org/10.1016/j.jbusres.2016.03.060

Andreeva, T., \& Garanina, T. (2017). Intellectual Capital and Its Impact on the Financial Performance of Russian
Manufacturing Companies. Foresight and STI Governance, 11(1), 31-40. https://doi. org/10.17323/2500-2597.2017.1.31.40.

Azmi, R. A. (2011). Business ethics as competitive advantage for companies in the globalization era. SSRN Electronic Journal. https://doi.org/10.2139/ssrn.1010073

Basuki, B., \& Sianipar, M. (2012). Intellectual capital and its impact on financial profitability and investors' capital gain on shares. Journal of Economics, Business, and Accountancy Ventura, 15(1), 101. https://doi.org/10.14414/jebav.v15i1.63

Bontis, N. (1998). Intellectual capital: An exploratory study that develops measures and models. Management Decision, 36(2), 63-76. https://doi.org/10.1108/00251749810204142

Bontis, N., Chua Chong Keow, W., \& Richardson, S. (2000). Intellectual capital and business performance in Malaysian industries. Journal of Intellectual Capital, 1(1), 85-100. https://doi.org/10.1108/14691930010324188

Bontis, N., Dragonetti, N. C., Jacobsen, K., \& Roos, G. (1999). The knowledge toolbox: A Review of the Tools Available to Measure and Manage Intangible. European Management Journal, 17(4), 391-402. https://doi.org/10.1016/S0263-2373(99)00019-5

Bontis, N., \& Fitz-enz, J. (2002). Intellectual capital ROI: A causal map of human capital antecedents and consequents. Journal of Intellectual Capital, 3(3), 223-247. https://doi. org/10.1108/14691930210435589

Bukh, P. N., Larsen, H. T., \& Mouritsen, J. (2001). Constructing intellectual capital statements. Scandinavian Journal of Management, 17(1), 87-108. https://doi. org/10.1016/S0956-5221(00)00034-8

Chen, J., Zhu, Z., \& Yuan Xie, H. (2004). Measuring intellectual capital: a new model and empirical study. Journal of Intellectual Capital, 5(1), 195-212. https://doi. org/10.1108/14691930410513003

Chi, C. G., \& Gursoy, D. (2009). Employee satisfaction, customer satisfaction, and financial performance: An empirical examination. International Journal of Hospitality Management, 28(2), 245-253. https://doi. org/10.1016/J.IJHM.2008.08.003

Chorev, S., \& Anderson, A. R. (2006). Success in Israeli high-tech start-ups; Critical factors and process. Technovation, 26(2), 162-174. https://doi.org/10.1016/J. TECHNOVATION.2005.06.014

Deeds, D. L. (2001). Role of R\&D intensity, 
technical development and absorptive capacity in creating entrepreneurial wealth in high technology start-ups. Journal of Engineering and Technology Management, 18(1), 29-47. https://doi.org/10.1016/S0923-4748(00)00032-1

Dženopoljac, V., Janoševic, S., \& Bontis, N. (2016). Intellectual capital and financial performance in the Serbian ICT industry. Journal of Intellectual Capital, 17(2), 373-396. https://doi.org/10.1108/JIC-07-2015-0068

Edvinsson, L. (1997). Developing intellectual capital at Skandia. Long Range Planning, 30(3), 366-373. https://doi.org/10.1016/S00246301(97)90248-X

Edvinsson, L., \& Malone, M. S. (1997). Intellectual Capital: Realizing Your Company's True Value by Finding Its Hidden Brainpower. New York, NY: Harper Collins Publishing.

Ferraro, O., \& Veltri, S. (2011). The value relevance of intellectual capital on the firm's market value: an empirical survey on the Italian listed firms. International Journal of KnowledgeBased Development, 2(1), 66-84. https://doi. org/10.1504/IJKBD.2011.040626

Firer, S., \& Mitchell, W. S. (2003). Intellectual capital and traditional measures of corporate performance. Journal of Intellectual Capital, 4(3), 348-360. https://doi. org/10.1108/14691930310487806

Gallego, I., \& Rodríguez, L. (2005). Situation of intangible assets in Spanish firms: An empirical analysis. Journal of Intellectual Capital, 6(1), 105-126. https://doi. org/10.1108/14691930510574690

Gubová, K., \& Richnák, P. (2016). Development and use of intangible assets in the conditions of globalization. In Globalization and its socio-economic consequences: 16th International scientific conference. Rajecké Teplice, Slovak Republic.

Hall, B. (1993). The stock market's valuation of R\&D investment during the 1980's. The American Economic Review, 83(2), 259-264. Retrieved October 16, 2020, from http://www. jstor.org/stable/2117674

Hall, R. (1992). The strategic analysis of intangible resources. Strategic Management Journal, 13(2), 135-144.

Haskel, J., \& Westlake, S. (2018). Capitalism without Capital: The Rise of the Intangible Economy. Princeton, NJ: Princeton University Press.

Hermanson, R. H. (1964). Accounting for Human Asset. East Lansing, MI: Michigan State University.
Hollis, E. (2004). Managing Intangible Assets Represents Opportunity for Learning Leaders. Atlanta, GA: Chief Learning Officer.

Hussinki, H., Ritala, P., Vanhala, M., \& Kianto, A. (2014). Intellectual capital, knowledge management practices and firm performance. Journal of Intellectual Capital, 18(4), 904-922. https://doi.org/10.1108/JIC-11-2016-0116

Kaplan, R. S., \& Norton, D. P. (1992). The Balanced Scorecard - Measures That Drive Performance. Harvard Business Review, 70(1), 71-79.

Kaplan, R. S., \& Norton, D. P. (2004). Strategy Maps: Converting Intangible Assets into Tangible Outcomes. Boston, MA: Harvard Business School Press.

Kianto, A., Sáenz, J., \& Aramburu, N. (2017). Knowledge-based human resource management practices, intellectual capital and innovation. Journal of Business Research, 81, 11-20. https://doi.org/10.1016/j. jbusres.2017.07.018

Komnenic, B., \& Pokrajčić, D. (2012). Intellectual capital and corporate performance of Serbian banks. Journal of Intellectual Capital, 13(1), 106-119. https://doi. org/10.1108/14691931211196231

Kozlenkova, I. V., Samaha, S. A., \& Palmatier, R. W. (2014). Resource-based theory in marketing. Journal of the Academy of Marketing Science, 42(1), 1-21. https://doi. org/10.1007/s11747-013-0336-7

Lantz, J.-S., \& Sahut, J.-M. (2005). R\&D investment and the financial performance of technological firms. International Journal of Business, 10(3), 251-270.

Malhotra, A. K., \& Mehrotra, V. (2019). Extent and gaps in intellectual capital disclosure in the Indian industry. International Journal of Learning and Intellectual Capital, 16(1), 1-20. https://doi.org/10.1504/ijlic.2019.10017047

Milosavljević, M., Dobrota, M., \& Milanović, N. (2019). A New Approach to the Evaluation of Public Procurement Efficiency among European Countries. European Review, 27(2), 246-259. https://doi.org/10.1017/S1062798718000777

Milosavljevic, M., Milanovic, N., \& Benkovic, S. (2017). Waiting for Godot: Testing Transparency, Responsiveness and Interactivity of Serbian Local Governments. Lex Localis - Journal of Local Self-Government, 15(3), 513-528. https:// doi.org/10.4335/15.3.513-528\%20(2017)

Mondal, A., \& Ghosh, S. K. (2012). Intellectual capital and financial performance of Indian banks. 
Journal of Intellectual Capital, 13(4), 515-530. https://doi.org/10.1108/14691931211276115

Nunnally, J. C. (1978). Psychometric Theory. New York, NY: McGraw-Hill.

Ordoñez de Pablos, P. (2005). Intellectual capital reports in India: lessons from a case study. Journal of Intellectual Capital, 6(1), 141-149. https://doi.org/10.1108/14691930510574717

Ordóñez de Pablos, P. (2003). Intellectual capital reporting in Spain: A comparative view. Journal of Intellectual Capital, 4(1), 61-81. https://doi.org/10.1108/14691930310455397

Palaščáková, D., Kol'veková, G., \& Melas, D. (2019). Analysis of State Investments into Human Capital in Slovak Republic. E\&M Economics and Management, 22(2), 114-128. https://doi.org/10.15240/tul/001/2019-2-008

Peterková, J., \& Zapletalová, Š. (2018). Evaluation of the Usability of Selected Innovation Concepts for Managing Innovation Activities. E\&M Economics and Management, 21(4), 141-158. https://doi.org/10.15240/ tul/001/2018-4-010

Pulić, A. (1998). Measuring the performance of intellectual potential in knowledge economy. Paper presented at the 2nd McMaster Word Congress on Measuring and Managing Intellectual Capital by the Austrian Team for Intellectual Potential.

Radonić, M., \& Milosavljević, M. (2019). Human Resource Practices, Failure Management Approaches and Innovations in Serbian Public Administration. Transylvanian Review of Administrative Sciences, 15(SI), 7793. https://doi.org/10.24193/tras.si2019.5

Radonić, M., \& Knežević, S. (2017). Application of the efficiency and profitability models through financial analysis in the function of competitiveness of domestic ICT companies. Info $M, 16(63), 45-50$.

Rakočević, S. B., Latinović, M., \& Milosavljević, M. (2014). Working Capital Management Practices and Financial Performance: Evidence from Serbia. In M. L. Jakšić, S. B. Rakočević, \& M. Martić (Eds.), Innovative Management and Firm Performance (pp. 254-275). London: Palgrave Macmillan. https://doi. org/10.1057/9781137402226_1

Riahi-Belkaoui, A. (2003). Intellectual capital and firm performance of US multinational firms. Journal of Intellectual Capital, 4(2), 215-226. https://doi.org/10.1108/14691930310472839

Sardo, F., \& Serrasqueiro, Z. (2017). A European empirical study of the relationship between firms' intellectual capital, financial performance and market value. Journal of Intellectual Capital, 18(4), 771-788. https://doi. org/10.1108/jic-10-2016-0105

Sougiannis, T. (1994). The Accounting Based Valuation of Corporate R\&D. The Accounting Review, 69(1), 44-68. Retrieved October 16, 2020, from http://www.jstor.org/stable/248260

Steenkamp, N., \& Kashyap, V. (2010). Importance and contribution of intangible assets: SME managers' perceptions. Journal of Intellectual Capital, 11(3), 368-390. https://doi. org/10.1108/14691931011064590

Sveiby, K. E. (1997). The Intangible Assets Monitor. Journal of Human Resource Costing \& Accounting, 2(1), 73-97. https://doi. org/10.1108/eb029036

Tsakalerou, M. (2018). Intellectual property as a key driver of business performance: the case of Singapore and its implications for innovation in a knowledge-based economy. International Journal of Learning and Intellectual Capital, 15(1), 83. https://doi.org/10.1504/ IJLIC.2018.088347

Vlastelica, T., Kostic, S. C., Okanovic, M., \& Milosavljevic, M. (2018). How Corporate Social Responsibility Affects Corporate Reputation: Evidence from an Emerging Market. Journal of East European Management Studies, 23(1), 1029. https://doi.org/10.5771/0949-6181-2018-1-10

Wahyuningtyas, R., Astuti, Y., \& Anggadwita, G. (2018). Identification of intellectual capital (IC) within micro-, small- and mediumsized enterprises (MSMEs): A case study of Cibuntu Tofu Industrial Center in Bandung, Indonesia. International Journal of Learning and Intellectual Capital, 15(1), 51. https://doi. org/10.1504/ijlic.2018.088344

Wang, J.-C. (2008). Investigating market value and intellectual capital for S\&P 500. Journal of Intellectual Capital, 9(4), 546-563. https://doi.org/10.1108/14691930810913159

Wang, W.-Y., \& Chang, C. (2005). Intellectual capital and performance in causal models. Evidence from the information technology industry in Taiwan. Journal of Intellectual Capital, 6(2), 222-236. https://doi. org/10.1108/14691930510592816

Zhang, N. (2017). Relationship between intangible assets and financial performance of listed telecommunication firms in China, based on empirical analysis. African Journal of Business Management, 11(24), 751-757. https://doi.org/10.5897/AJBM2017.8429 


\section{Appendix}

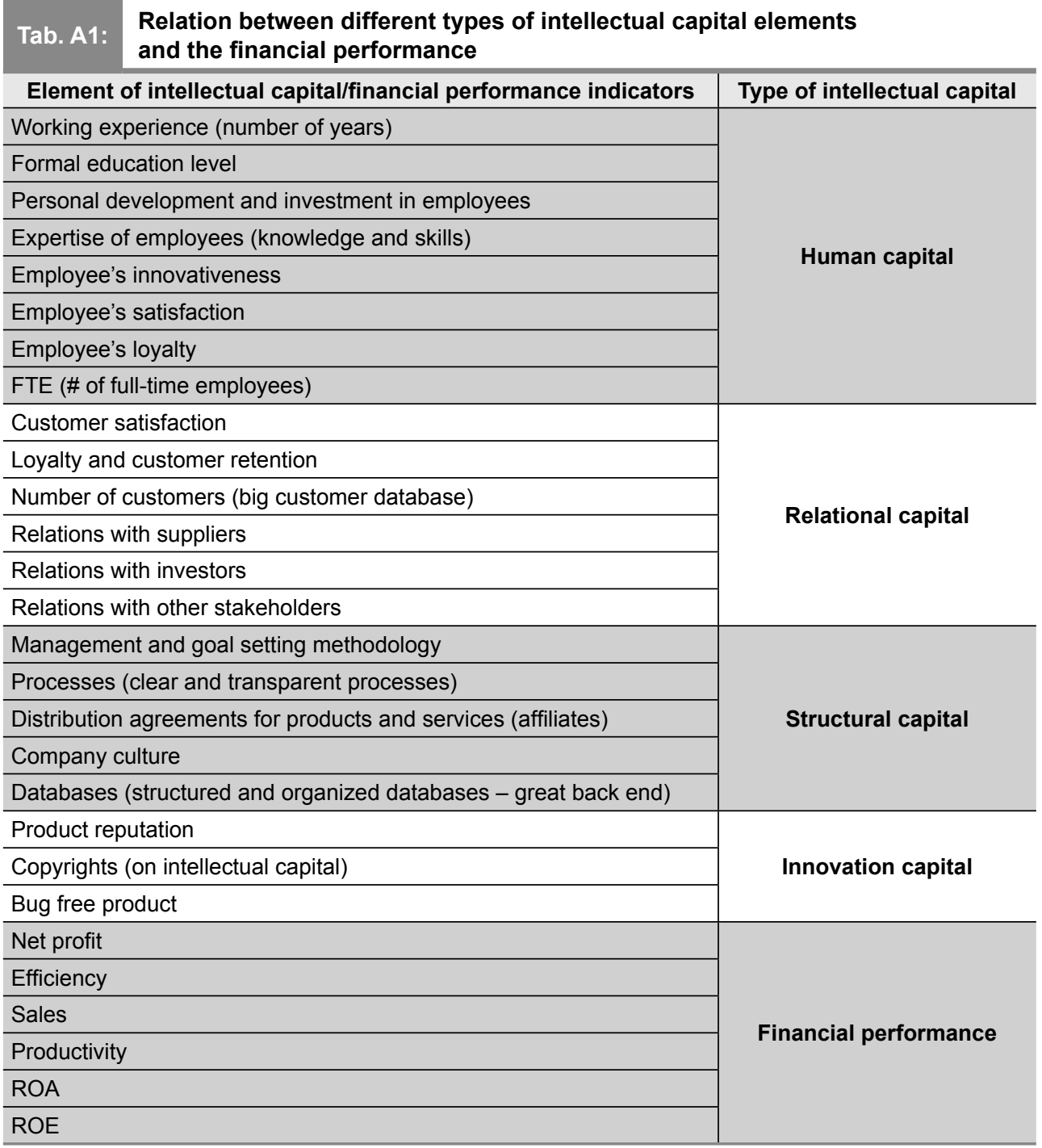

